\title{
Analisis kesulitan belajar mahasiswa Pada materi integral
}

\author{
Erma Monariska \\ Program Studi Pendidikan Matematika, Fakultas Keguruan dan Ilmu Pendidikan, \\ Universitas Suryakancana, Jl. Dr. Muwardi Kompleks Pasir Gede Raya, Cianjur, \\ ermamonariska@unsur.ac.id
}

DOI : 10.15575/ja.v5i1.4181

Received: 03 Januari 2019 ; Accepted: 18 Mei 2019 ; Published: 29 Juni 2019

\begin{abstract}
ABSTRAK
Sebagian besar mahasiswa menganggap bahwa materi integral merupakan materi yang sulit dipahami. Oleh karena itu perlu adanya suatu kajian tentang kesulitan mahasiswa pada materi integral dan faktor apa sajakah yang menyebabkan kesulitan tersebut mengingat sangat pentingnya konsep ini dalam menempuh mata kuliah berikutnya. Metode penelitian menggunakan metode deskriptif kualitatif. Pada penelitian ini, subjeknya adalah mahasiswa tingkat II Program Studi Pendidikan Matematika Universitas Suryakancana. Teknik Pengumpulan data dilakukan dengan menggunakan instrumen tes dan wawancara. Hasil penelitian menunjukkan bahwa kesulitan belajar yang dialami mahasiswa terletak pada kemampuan matematis mahasiswa dalam menyelesaikan soal-soal integral. Kemampuan tersebut meliputi lemahnya pemahaman mahasiswa terhadap teorema dasar kalkulus terutama pada konsep turunan. Kesulitan yang dialami mahasiswa terletak pada kesalahan dalam memahami soal, kesalahan dalam keterampilan proses serta kesalahan karena kurang cermat dalam mengerjakan soal dan mengelola waktu yang disediakan sehingga soal tidak dapat terselesaikan dengan baik. Adapun faktor penyebab kesulitan belajar mahasiswa pada materi integral adalah kurangnya latihan dalam mengerjakan soal-soal integral dan lemahnya pemahaman mahasiswa terhadap konsep teorema dasar kalkulus. Setelah dilakukan analisis dan kajian tentang masalah ini diharapkan adanya perbaikan baik dalam segi kurikulum, metode pembelajaran maupun pengembangan bahan ajar.
\end{abstract}

Kata kunci: Kesulitan Belajar, Materi Integral

\begin{abstract}
Most students assume that integral material is an elusive material. Therefore, there is a need for a study of the difficulties of students in integral material and what factors cause these difficulties given the very importance of this concept in taking the next course. The research method uses a qualitative descriptive method. In this study, the subjects were second-level students of the Mathematics Education Study Program at Suryakancana University. Data collection techniques are carried out using test instruments and interviews. The results showed that the learning difficulties experienced by students lay in the students' mathematical ability to solve integral questions. These capabilities include the weakness of students' understanding of the basic theorem of calculus, especially in the concept of derivatives. Difficulties experienced by students lie in errors in understanding the problem, errors in process skills and errors because they are not careful in working on the problem and managing the time provided so that the problem cannot be solved properly. The factors that cause student learning difficulties in integral material are the lack of training in working on integral questions and the weak understanding of students about the concept of the basic calculus theorem. After analysis and study of this problem, it is expected that there will be improvements both in terms of curriculum, learning methods and the development of teaching materials.
\end{abstract}

Keywords: Learning Difficulties, Integral Material 


\section{PENDAHULUAN}

Integral merupakan konsep yang penting dalam kalkulus selain turunan. Integral merupakan operasi utama didalam kalkulus integral. Prinsip-prinsip integral diformulasikan oleh Isaac Newton dan Gottfried Leibniz pada abad 17 dengan memanfaatkan hubungan erat antara anti turunan dan integral tentu yaitu suatu hubungan yang memungkinkan kita untuk menghitung nilai yang sebenarnya dari banyak integral tentu dengan menggunakan teorema dasar kalkulus. Melalui teorema ini mereka mengembangkan konsep integral yang dikaitkan dengan turunan, sehingga integral didefinisikan sebagai anti turunan karena keduanya memiliki hubungan yang saling berkebalikan.

Integral memiliki peranan yang penting dalam berbagai bidang sains dan industri. Integral juga banyak dipergunakan dalam memecahkan persoalan dalam berbagai bidang seperti volume, panjang kurva, perkiraan populasi, usaha, dan lain-lain.

Di Indonesia, konsep integral mulai diberikan pada siswa Sekolah Menengah Atas (SMA) dan berlanjut untuk diperdalam di perguruan tinggi. Pada perguruan tinggi, konsep integral merupakan konsep utama dalam kalkulus integral yang merupakan bagian dari mata kuliah kalkulus setelah kalkulus diferensial dan berlanjut pada kalkulus peubah banyak. Kalkulus merupakan cabang ilmu matematika yang merupakan pintu gerbang menuju pelajaran matematika lainnya yang lebih tinggi, yang khusus mempelajari fungsi dan limit, yang secara umum dinamakan analisis matematika. (Wikipedia.org).

Kalkulus merupakan mata kuliah dasar yang merupakan salah satu prasyarat untuk menempuh mata kuliah lain. Sehingga dengan pemahaman yang benar terhadap mata kuliah ini diharapkan mahasiswa tidak menemukan kesulitan yang berarti pada saat menempuh mata kuliah lain seperti persamaan differensial biasa, analisis real, statistika matematika, dan lain-lain. Oleh karena itu, pada program studi pendidikan matematika Universitas Suryakancana, kalkulus merupakan mata kuliah wajib bagi mahasiswa yang diberikan dalam tiga semester, yang terdiri dari kalkulus differensial, kalkulus integral dan kalkulus peubah banyak. Ketiganya saling berkesinambungan karena pada dasarnya mahasiswa akan mengalami kesulitan dalam memahami materi kalkulus integral apabila kalkulus differensial tidak dipahami secara benar. Mata kuliah ini berkelanjutan terlebih lagi ketika mahasiswa dihadapkan pada mata kuliah kalkulus peubah banyak yang dasar konsepnya ada pada kalkulus differensial dan kalkulus integral. Sehingga pemahaman awal mahasiswa akan menentukan ketuntasan untuk mata kuliah selanjutnya. Namun dalam prakteknya, kalkulus merupakan mata kuliah yang sulit dalam menyelesaikan masalahnya, hal ini sesuai dengan pendapat NP Loc dalam Nguyen Phu Loc dan Tran Cong Thai Ho yaitu:

"Calculus have highly intrinsic complexity and often involves infinite process; therefore, students will encounter difficulties and obstacles while studying the subject, and will commit many errors when solving calculus problem"

Kalkulus memiliki kompleksitas intrinsik dan sering melibatkan proses penyelesaian yang tak terbatas. Oleh karena itu, seseorang akan mengalami kesulitan dan hambatan saat mempelajarinya dan akan melakukan banyak kesalahan saat memecahkan masalah kalkulus. Kesulitan belajar adalah suatu kondisi dimana mahasiswa tidak dapat belajar secara wajar, disebabkan karena ancaman, hambatan, ataupun gangguan dalam belajar [Djamarah, 2008]. Lerner (1981) berpendapat bahwa kesulitan belajar adalah istilah umum untuk berbagai jenis kesulitan dalam menyimak, berbicara, membaca, menulis, dan berhitung. Kondisi ini bukan karena kecacatan fisik atau mental, bukan juga karena faktor lingkungan, melainkan karena faktor kesulitan dari dalam individu itu sendiri saat mempersepsi dan melakukan pemrosesan informasi terhadap 
objek yang diinderainya. Selanjutnya, Mulyadi (2010) mengatakan bahwa kesulitan belajar adalah kondisi dalam suatu proses belajar yang ditandai adanya hambatan-hambatan tertentu untuk mencapai hasil belajar. Lebih lanjut, Djamarah (2008) mengatakan bahwa salah satu gejala indikator kesulitan belajar adalah mahasiswa menunjukkan hasil belajar yang rendah, dibawah rata-rata nilai yang dicapai oleh kelompok mahasiswa lain dikelas.

Berdasarkan hasil wawancara awal yang dilakukan peneliti terhadap beberapa mahasiswa pendidikan matematika, mereka mengatakan bahwa kalkulus merupakan salah satu mata kuliah yang sangat sulit untuk dipahami karena memerlukan pemahaman konsep yang mendalam dan pemahaman yang benar terhadap materi-materi prasyarat yang telah dipelajari di SMA. Namun demikian, mereka mengakui bahwa mata kuliah kalkulus merupakan mata kuliah yang penting karena berisi konsep-konsep dasar matematika yang akan sangat diperlukan dalam memecahkan berbagai permasalahan dalam berbagai bidang, terutama akan juga sangat diperlukan pada saat mereka mengajarkan konsep-konsep matematika dasar persekolahan ketika mereka menjadi guru.

Mengingat sangat pentingnya konsep integral khususnya bagi mahasiswa lulusan Fakultas Keguruan dan Ilmu Pendidikan yang kemudian akan memberikan kontribusi yang sangat besar dalam dunia pendidikan, maka peneliti ingin mengetahui dan menelaah kesulitan-kesulitan mahasiswa pada materi integral melalui penelitian yang berjudul "Analisis Kesulitan Belajar Mahasiswa pada Materi Integral”.

Berdasarkan latar belakang masalah diatas, maka permasalahan tersebut dijabarkan sebagai berikut :

1. Kesulitan apa yang dialami mahasiswa dalam menyelesaikan soal Integral?

2. Faktor-faktor apa saja yang menyebabkan kesulitan mahasiswa dalam menyelesaikan soal integral?

\section{METODE}

Metode penelitian yang digunakan dalam penelitian ini adalah metode penelitian deskriptif kualitatif (Sugiyono, 2011). Hal ini bertujuan untuk mengetahui dan menelaah kesulitan mahasiswa pada materi integral dan menemukan faktor-faktor penyebab kesulitan mahasiswa dalam menyelesaikan soal integral. Subjek penelitiannya yaitu mahasiswa tingkat II semester empat Program Studi Pendidikan matematika Universitas Suryakancana Tahun Akademik 2017-2018 sebanyak 42 orang yang menempuh mata kuliah Kalkulus Integral dan telah menempuh mata kuliah Kalkulus Differensial yang memuat materi prasyarat yaitu konsep turunan/ differensial pada semester sebelumnya. Penelitian dilakukan dengan mengumpulkan informasi baik melalui tes maupun wawancara. Tes dilakukan untuk mengetahui letak dan jenis kesulitan mahasiswa dalam menyelesaikan soal-soal yang berhubungan dengan integral berdasarkan hasil pengerjaan mahasiswa. Adapun wawancara dilakukan untuk mengetahui jawaban lisan secara langsung mengenai kesulitan-kesulitan yang dialami mahasiswa pada materi integral. Wawancara ini akan berfungsi dalam melengkapi dan memperkuat data hasil tes tertulis, serta mengungkapkan hal-hal yang tidak terungkap dalam tes tertulis. Dengan demikian, akan diperoleh gambaran secara lengkap mengenai kesulitan belajar yang dialami oleh mahasiswa pada materi integral tersebut.

Teknik analisis data yang digunakan adalah deskriptif naratif dengan menggunakan model Miles dan Huberman. Miles dan Huberman (Sugiyono, 2011), mengemukakan bahwa aktivitas dalam analisis data kualitatif dilakukan secara interaktif dan berlangsung secara terus menerus sampai tuntas, sehingga datanya jenuh. Analisis data yang digunakan dalam penelitian ini terdiri dari empat bagian penting, yaitu pengumpulan data, reduksi data, penyajian data, dan kesimpulan hasil penelitian. 


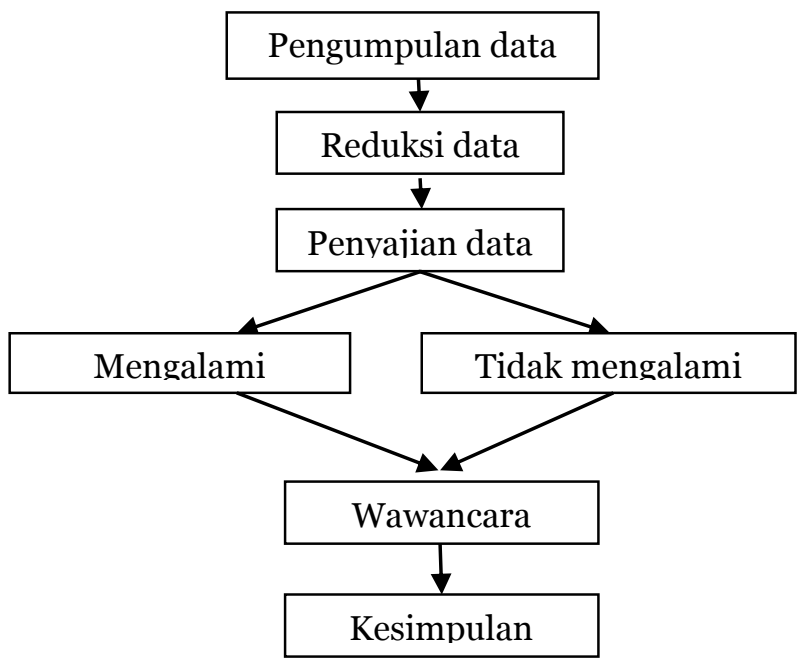

\section{Gambar 1 Model Analisis Data menurut Miles dan Huberman}

\section{HASIL DAN PEMBAHASAN}

Berdasarkan hasil jawaban soal tes, peneliti memperoleh data-data yang dapat menunjukkan bahwa mahasiswa mengalami kesulitan belajar pada materi integral. Prosentase kesulitan belajar yang dialami mahasiswa pada tiap sub materi integral dapat dilihat pada Tabel 1 berikut.

Tabel 1. Prosentase Kesulitan Belajar pada Setiap Sub Materi

\begin{tabular}{|c|c|c|c|}
\hline \multirow[b]{2}{*}{ Sub Materi } & \multirow[b]{2}{*}{$\begin{array}{l}\text { No. } \\
\text { Soal }\end{array}$} & \multicolumn{2}{|c|}{ Kategori (dalam \%) } \\
\hline & & $\begin{array}{c}\text { Mengala } \\
\text { mi } \\
\text { Kesulita } \\
\text { n } \\
\text { Belajar }\end{array}$ & $\begin{array}{c}\text { Tidak } \\
\text { mengala } \\
\text { mi } \\
\text { Kesulitan } \\
\text { Belajar }\end{array}$ \\
\hline $\begin{array}{l}\text { Menyelesaik } \\
\text { an integral } \\
\text { sederhana } \\
\text { dengan } \\
\text { menggunaka } \\
\text { n rumus } \\
\text { dasar } \\
\text { kalkulus }\end{array}$ & 9 & 71 & 29 \\
\hline
\end{tabular}

\begin{tabular}{|c|c|c|c|}
\hline $\begin{array}{l}\text { Menyelesaik } \\
\text { an integral } \\
\text { sederhana } \\
\text { dengan } \\
\text { menggunaka } \\
\text { n rumus } \\
\text { dasar } \\
\text { kalkulus } \\
\text { (pengantar } \\
\text { kepada } \\
\text { persamaan } \\
\text { diferensial) }\end{array}$ & 10 & 71 & 29 \\
\hline Integral & 1 & 88 & 12 \\
\hline $\begin{array}{l}\text { fungsi } \\
\text { trigonometri }\end{array}$ & 5 & 86 & 14 \\
\hline $\begin{array}{l}\text { Integral } \\
\text { fungsi } \\
\text { eksponen }\end{array}$ & 2 & 83 & 17 \\
\hline $\begin{array}{l}\text { Integral } \\
\text { fungsi } \\
\text { logaritma asli }\end{array}$ & 3 & 83 & 17 \\
\hline $\begin{array}{l}\text { Integral } \\
\text { fungsi aljabar } \\
\text { (substitusi } \\
\text { yang } \\
\text { merasionalka } \\
\text { n) }\end{array}$ & 4 & 76 & 24 \\
\hline $\begin{array}{l}\text { Integral } \\
\text { fungsi } \\
\text { rasional }\end{array}$ & 6 & 69 & 31 \\
\hline Substitusi & 7 & 69 & 31 \\
\hline $\begin{array}{l}\text { pada integral } \\
\text { tentu }\end{array}$ & 8 & 71 & 29 \\
\hline Rata-rata & & 77 & 23 \\
\hline
\end{tabular}

Hasil tes terhadap materi integral berdasarkan tabel diatas, diketahui bahwa kesulitan belajar tertinggi terdapat pada materi integral pada fungsi trigonometri dengan prosentase sebesar 88\%. Secara keseluruhan, rata-rata prosentase kesulitan belajar pada materi integral adalah sebesar $77 \%$.

\section{Analisis Dokumen Hasil Tes}


1. Pada materi menyelesaikan integral sederhana dengan menggunakan rumus dasar kalkulus pada nomor 9, kesalahan yang dilakukan mahasiswa dalam menyelesaikan soal ini diantaranya adalah kurang memahami soal sehingga tidak dapat menyelesaikan soal dengan benar dan kurang memahami konsep fungsi. Berikut adalah contoh hasil jawaban mahasiswa yang menunjukkan bahwa siswa kurang memahami maksud dari soal (gambar 2) dan kurang memahami konsep fungsi (gambar 3).

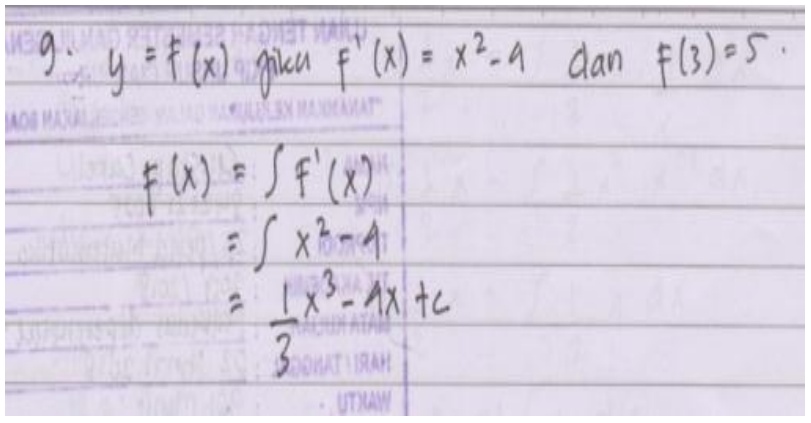

Gambar 2. Jawaban Mahasiswa pada Soal Nomor 9

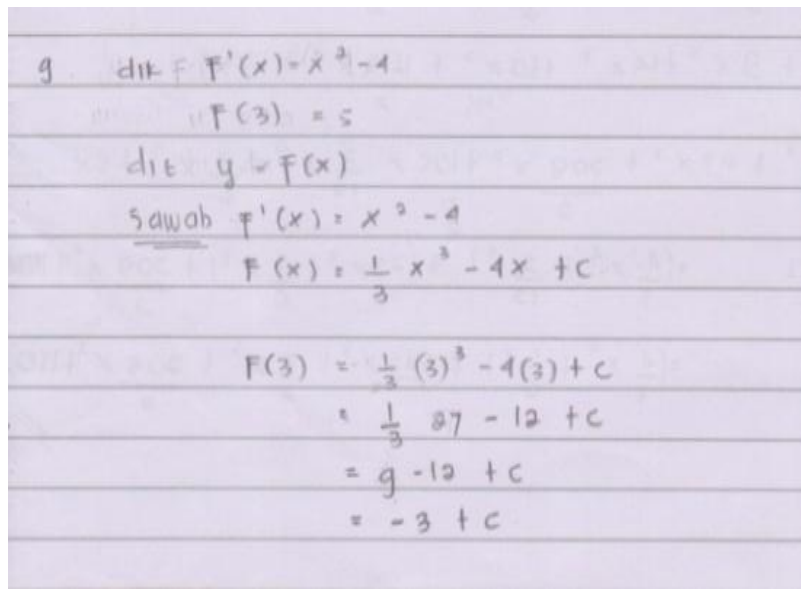

Gambar 3. Jawaban Mahasiswa pada Soal Nomor 9

Pada gambar 2 terlihat bahwa mahasiswa melakukan pengintegralan dalam bentuk sederhana dengan benar, tapi soal ini menginginkan bentuk fungsi $\mathrm{f}(\mathrm{x})$ yang lebih khusus dengan memasukkan nilai $\mathrm{f}(3)=5$ untuk mendapatkan fungsi baru dan itu tidak dilakukan oleh mahasiswa. Sementara dari gambar 3 tampak bahwa mahasiswa melupakan konsep bahwa $\mathrm{f}(3)=$ 5, maka seharusnya pada penyelesaian berikutnya $\mathrm{f}(3)$ digantikan dengan 5 sehingga didapatkan nilai $\mathrm{C}$ dan nilai $\mathrm{C}$ ini dimasukkan kedalam $\mathrm{f}(\mathrm{x})$ sehingga terbentuklah fungsi yang baru sebagaimana diharapkan dari soal.

2. Pada materi menyelesaikan integral sederhana dengan menggunakan rumus dasar kalkulus (pengantar kepada persamaan differensial) pada nomor 10, kesalahan yang dilakukan mahasiswa dalam menyelesaikan soal ini diantaranya adalah kesalahan penulisan dan perhitungan algoritma serta kurang menguasai konsep integral. Contoh hasil jawaban mahasiswa ditunjukkan pada gambar 4 berikut. 


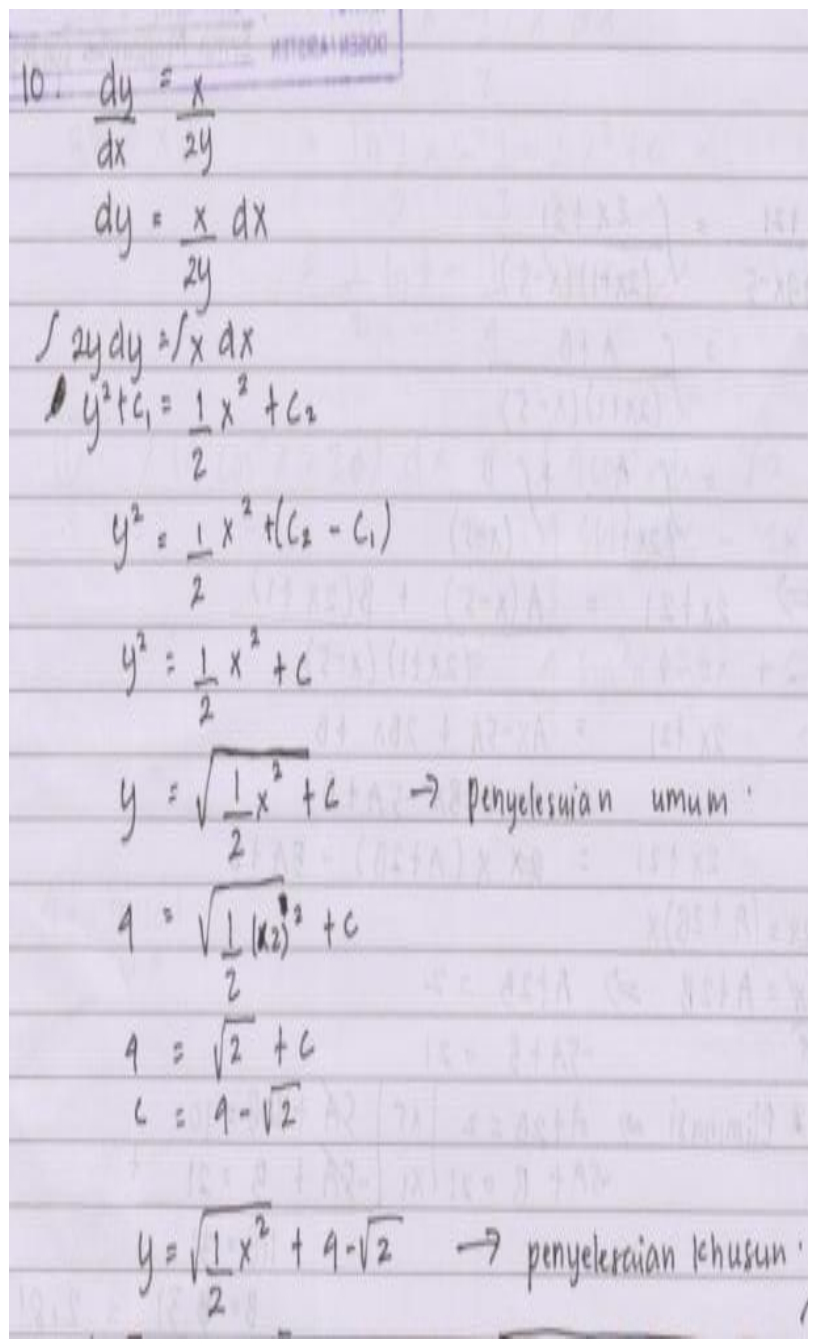

$\begin{aligned} \text { dit } f f^{\prime}(x) & =x^{2}-4 \\ f(3) & =5 \\ \text { dit } y-f(x) & \\ \text { Sawab } f^{\prime}(x) & =x^{2}-4 \\ f(x) & =\frac{1}{3} x^{3}-4 x+c \\ F(3) & =\frac{1}{3}(3)^{3}-4(3)+c \\ & =\frac{1}{3}-27-12+c \\ & =g-12+c \\ & =-3+c \\ & \end{aligned}$

\section{Gambar 4. Jawaban Mahasiswa pada Soal Nomor 10}

3. Pada materi Integral fungsi trigonometri pada nomor 1 dan nomor 5 , kesalahan yang dilakukan mahasiswa dalam menyelesaikan soal ini diantaranya adalah kesalahan penulisan dan perhitungan algoritma, kurang menguasai konsep integral pada trigonometri, serta lemahnya kemampuan mahasiswa pada materi trigonometri itu sendiri dan kurang cermat dalam mengelola waktu dalam mengerjakan soal sehingga soal tidak dapat diselesaikan sampai akhir. Contoh hasil jawaban mahasiswa ditunjukkan pada gambar 5 dan 6 berikut.

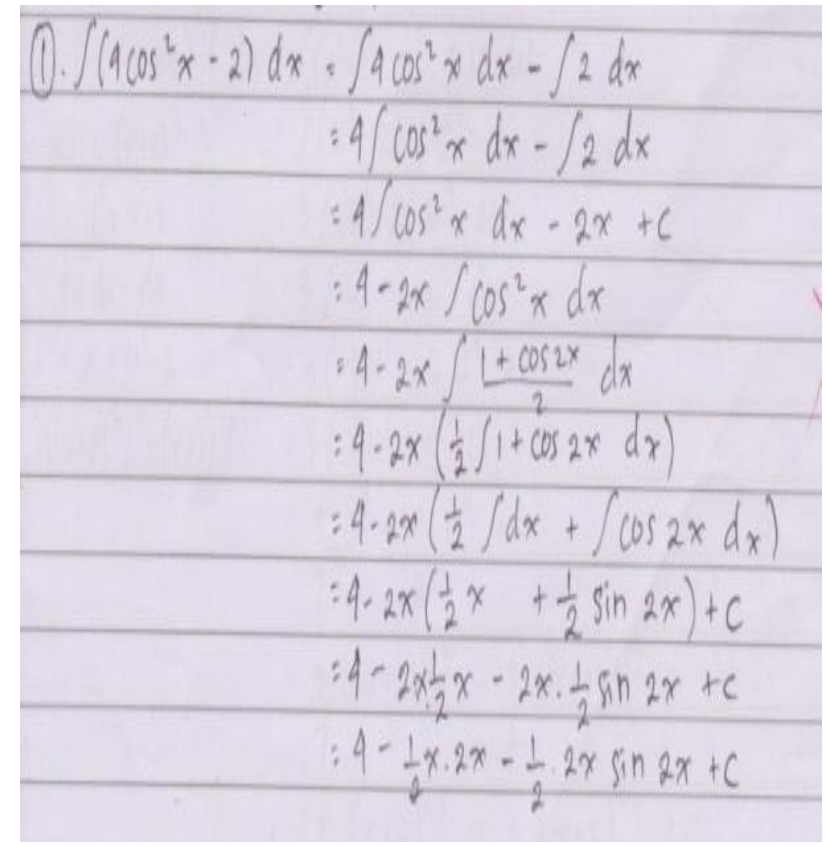

Gambar 5. Jawaban Mahasiswa pada Soal Nomor 1 


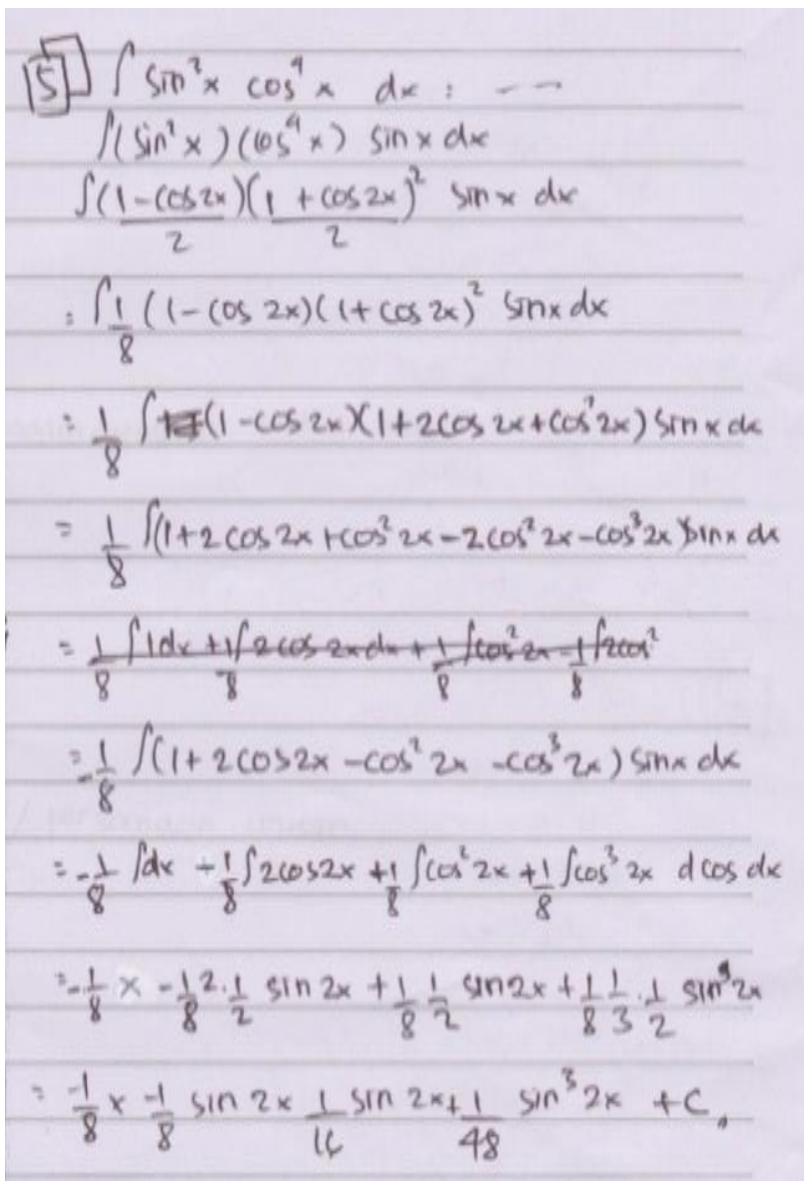

Gambar 6. Jawaban Mahasiswa pada Soal Nomor 5

4. Pada materi Integral fungsi eksponen pada nomor 2, kesalahan yang dilakukan mahasiswa dalam menyelesaikan soal ini diantaranya adalah kesalahan penulisan simbol dan algoritma termasuk lupa mengembalikan simbol pemisalan ke bentuk asal, kesalahan dalam melakukan pengintegralan (dalam soal ini adalah melakukan pengintegralan parsial), serta kurang pahamnya mahasiswa dalam melakukan pengintegralan. Contoh hasil jawaban mahasiswa ditunjukkan pada gambar 7 berikut.

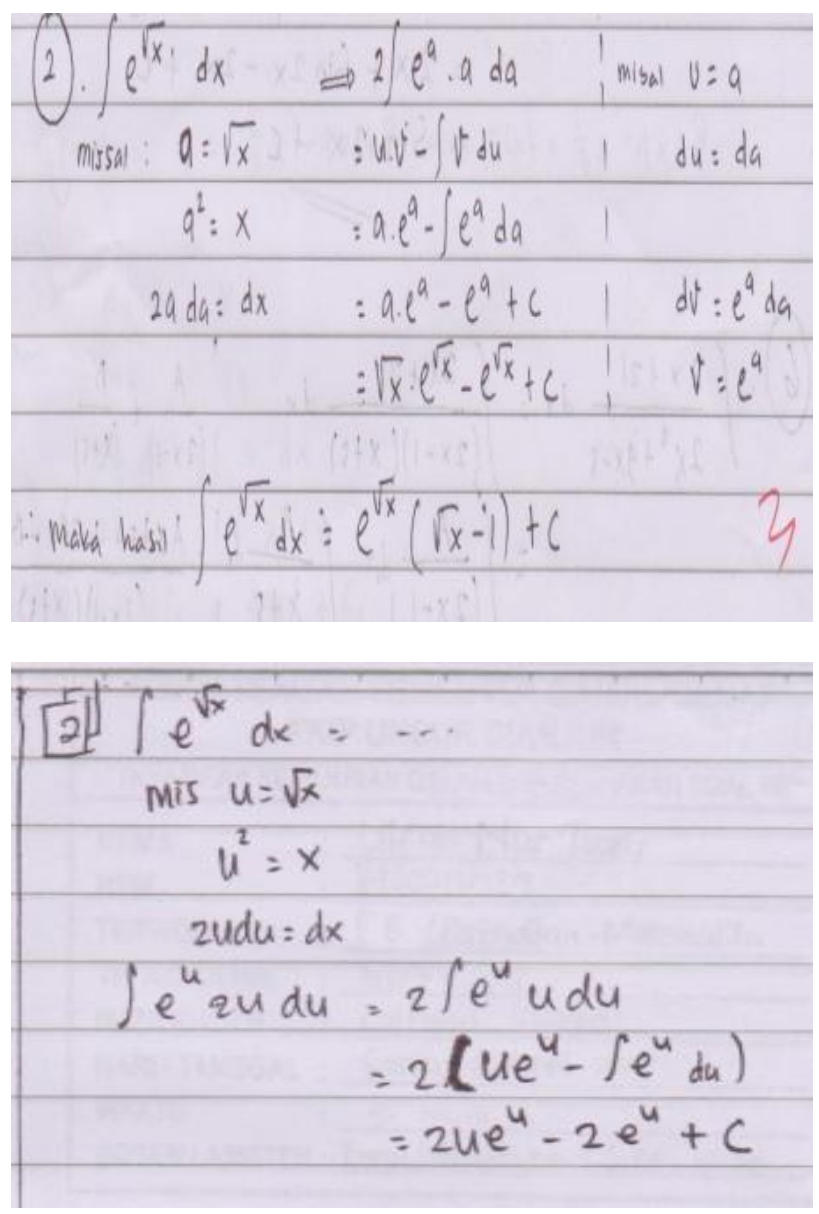

$\begin{array}{rlrl}\text { 2. } \int e^{\sqrt{x}} d x= & \Rightarrow \int e^{\sqrt{x}} d x & =\int e^{u} 2 u d u \\ \text { misal }=u=\sqrt{x} & & =e^{u} u^{2}+c \\ d u & =\frac{1}{2 \sqrt{x}} d x & & =e^{\sqrt{x}} \sqrt{x}+c \\ 2 u d u & =d x & & =e^{\sqrt{x}} \cdot x+c=x e^{\sqrt{x}}+c\end{array}$

Gambar 7. Jawaban Mahasiswa pada Soal Nomor 2

5. Pada materi Integral fungsi logaritma asli pada nomor 3, pada soal ini mahasiswa sudah mengetahui teknik pengintegralan parsial yang harus dilalui untuk dapat menyelesaikan soal ini namun kesalahan yang dilakukan mahasiswa adalah kesalahan dalam menentukan pemisalan 
dalam pengintegralan parsial artinya mahasiswa kurang pandai dan kurang paham dalam melakukan teknik pengintegralan parsial. Contoh hasil jawaban mahasiswa ditunjukkan pada gambar 8 berikut.

$\begin{aligned} \text { 3. } \int \ln ^{2} x d x & =\ln \frac{1}{2} x-\int \frac{1}{2} x \cdot \frac{1}{x} d x \\ \text { misal } & =\ln \frac{1}{2} x-\int \frac{1}{2} x^{2} \cdot x^{-1} d x \\ d u=\frac{1}{x} d x & =\ln \frac{1}{2} x-\int \frac{1}{2} x d x \\ d v=x & =\ln \frac{1}{2} x-\frac{1}{2} \int \frac{1}{2} d x \\ v=\frac{1}{2} x^{2} d x & =\ln \frac{1}{2} x-\frac{1}{2} \cdot \frac{1}{2} x^{2}+c \\ 2 v=x d x & =\frac{1}{2} \ln x-\frac{1}{2} x^{2}+c\end{aligned}$

Gambar 8. Jawaban Mahasiswa pada Soal Nomor 3

6. Pada materi Integral fungsi aljabar (substitusi yang merasionalkan) pada nomor 4, kesalahan yang dilakukan mahasiswa dalam menyelesaikan soal ini diantaranya adalah kesalahan perhitungan algoritma serta kurang pahamnya mahasiswa dalam melakukan substitusi yang merasionalkan. Contoh hasil jawaban mahasiswa ditunjukkan pada gambar 9 berikut.

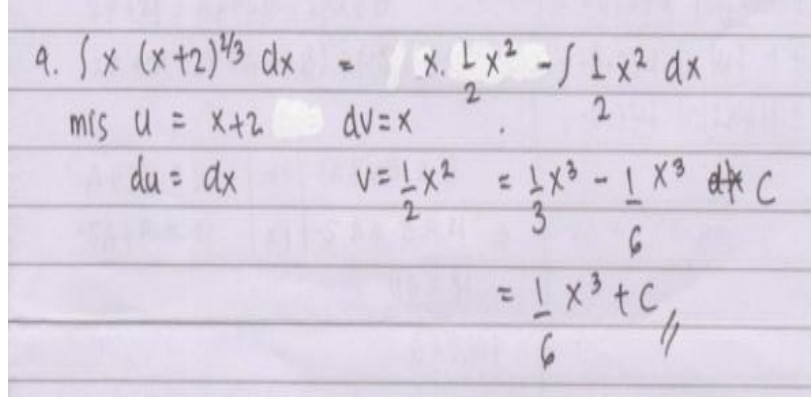

Gambar 9. Jawaban Mahasiswa pada Soal Nomor 4
7. Pada materi integral fungsi rasional pada nomor 6, kesalahan yang dilakukan mahasiswa dalam menyelesaikan soal ini diantaranya adalah kesalahan dalam perhitungan algoritma, kesalahan dalam memfaktorkan penyebut, kesalahan dalam menyusun hasil pengintegralan fungsi rasional, serta kurang pahamnya mahasiswa dalam melakukan integral pada fungsi rasional.

Contoh hasil jawaban mahasiswa pada soal nomor 6 ditunjukkan pada gambar 9 berikut.

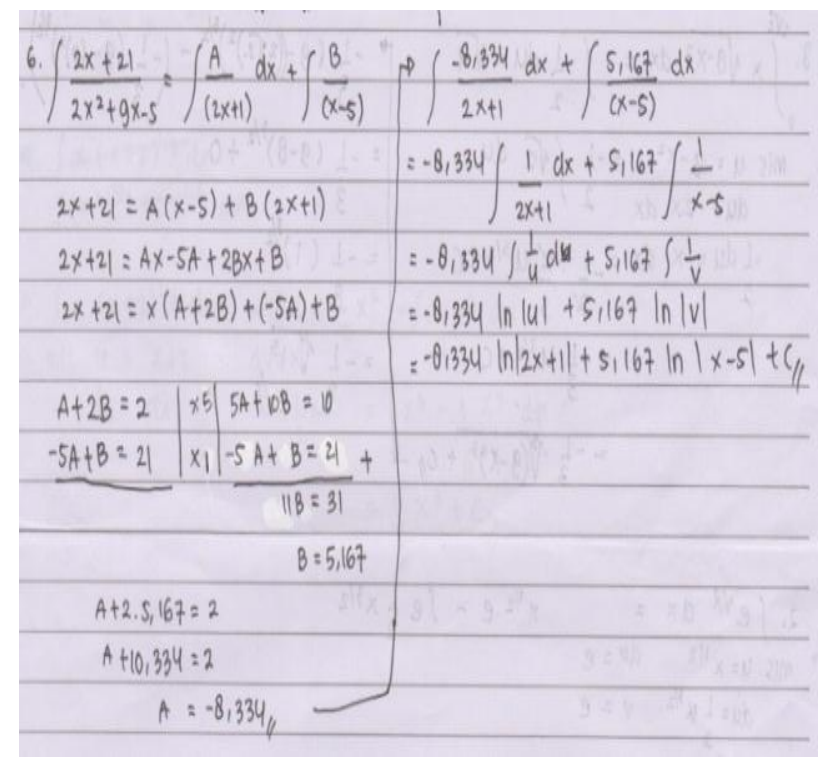

\section{Gambar 10. Jawaban Mahasiswa pada Soal Nomor 6}

8. Pada materi Substitusi pada integral tentu pada nomor 7 dan 8, kesalahan yang dilakukan mahasiswa dalam menyelesaikan soal ini diantaranya adalah kesalahan perhitungan algoritma, kesalahan algoritma pada penghitungan integral tentu, ketepatan menggunakan teknik integrasi dalam menyelesaikan soal, serta kurang pahamnya mahasiswa dalam menyelesaikan soal integral tentu. Contoh hasil jawaban mahasiswa ditunjukkan pada gambar 11 dan 12 berikut. 


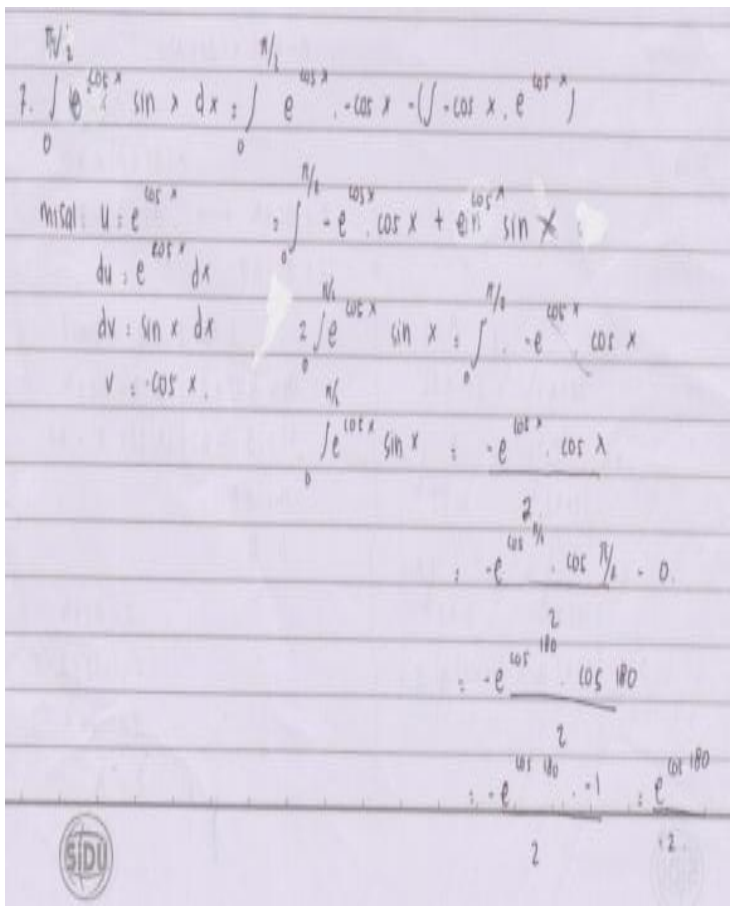

Gambar 11. Jawaban Mahasiswa pada Soal Nomor 7

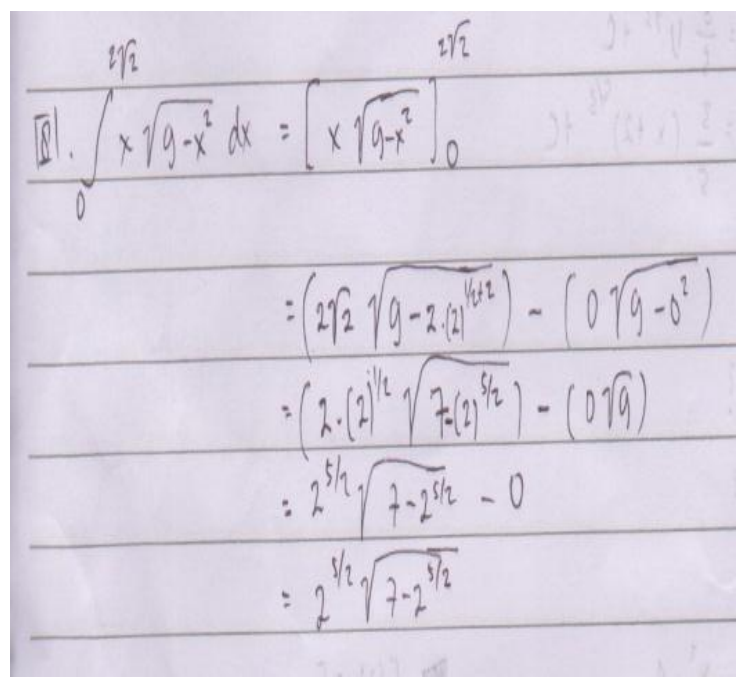

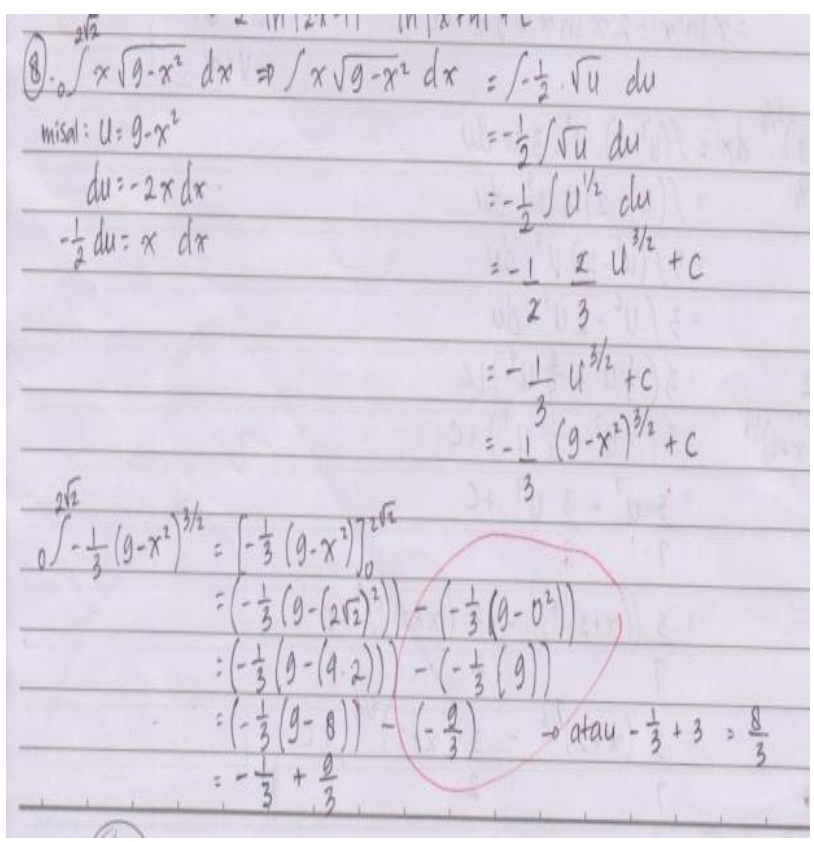

\section{Gambar 12. Jawaban Mahasiswa pada Soal Nomor 8}

Analisis dokumen hasil tes diatas, terlihat banyaknya kesalahan-kesalahan yang dilakukan mahasiswa. Kesalahan-kesalahan ini menunjukkan bahwa mahasiswa mengalami kesulitan belajar pada materi integral. Untuk dapat menyelesaikan persoalan integral dibutuhkan pemahaman yang kuat terhadap teorema dasar kalkulus disamping penguasaan yang tinggi terhadap konsep-konsep materi prasyarat yang sangat dibutuhkan dalam menyelesaikan materi integral ini seperti konsep turunan, fungsi (termasuk fungsi aljabar, eksponen, trigonometri, rasional, logaritma asli, dan lain-lain). Inilah yang menunjukkan bahwa matematika adalah ilmu mengenai struktur yang mencakup hubungan, pola maupun bentuk. Matematika berkenaan dengan ide-ide (gagasan-gagasan), strukturstruktur dan hubungannya diatur secara logis sehingga matematika berkaitan dengan konsepkonsep yang abstrak yang tersusun secara hierarkis dan penalarannya deduktif. Oleh karena itu, dalam matematika pemahaman terhadap konsep yang satu akan mempengaruhi pemahaman terhadap konsep yang lainnya. Semakin kuat pemahaman seseorang terhadap 
suatu konsep akan mempermudah pemahaman orang tersebut terhadap konsep berikutnya.

\section{Analisis Dokumen Hasil Wawancara}

Berdasarkan hasil wawancara yang dilakukan peneliti terhadap mahasiswa, diperoleh bahwa pada prinsipnya mahasiswa memahami konsep-konsep dalam materi integral, akan tetapi ketika mengerjakan soal mahasiswa mengalami kebingungan dalam menentukan cara atau teknik integrasi yang harus digunakan dalam menyelesaikan soal, walaupun pada saat dosen menjelaskan materi, mereka sudah memahaminya. Berikut adalah faktor-faktor yang menyebabkan mahasiswa mengalami kesulitan dalam menyelesaikan soal-soal materi integral berdasarkan hasil wawancara yang telah dirangkum, yaitu :

1. Pada materi menyelesaikan integral sederhana dengan menggunakan rumus dasar kalkulus, mahasiswa kurang memahami soal sehingga tidak dapat menyelesaikan soal dengan benar dan kurang memahami konsep fungsi dan konsep integral itu sendiri.

2. Pada materi menyelesaikan integral sederhana dengan menggunakan rumus dasar kalkulus (pengantar kepada persamaan diferensial), mahasiswa kurang menguasai konsep integral sehingga menyebabkan kesalahan penulisan dan perhitungan algoritma.

3. Pada materi Integral fungsi trigonometri, mahasiswa kurang memahami konsep trigonometri sehingga banyak melakukan kesalahan dalam mengubah-ubah integran dan mengalami kebingungan dalam menyelesaikan integral fungsi trigonometri sehingga terjadi banyak kesalahan penulisan dan perhitungan algoritma dan tidak dapat mengerjakan soal dengan benar.

4. Pada materi Integral fungsi eksponen, mahasiswa kesulitan dalam menentukan teknik integrasi yang tepat untuk digunakan dalam menyelesaikan soal ini. Beberapa mahasiswa menggunakan teknik yang benar yaitu pengintegralan parsial namun juga melakukan kesalahan dalam melakukan pengintegralan parsial terutama dalam memisalkan integran sehingga tidak dapat menyelesaikan soal dengan benar.

5. Pada materi Integral fungsi logaritma asli, pada soal ini digunakan integral parsial berulang namun dengan kondisi yang sama. Dalam hal ini, mahasiswa mengetahui teknik pengintegralan parsial yang harus dilalui untuk dapat menyelesaikan soal ini namun mahasiswa kebingungan dalam menentukan pemisalan integrannya yaitu mana $\mathrm{u}$ dan mana dv sehingga pemisalan yang tidak tepat ini menyebabkan soal tidak dapat diselesaikan dengan benar.

6. Pada materi Integral fungsi aljabar (substitusi yang merasionalkan), mahasiswa melakukan kesalahan dalam menentukan $\mathrm{u}$ dan $\mathrm{dv}$ kemudian memasukkannya kedalam integran yang akan diintegralkan, kesalahan ini menyebabkan kesalahan perhitungan algoritma serta soal tidak dapat diselesaikan dengan benar.

7. Pada materi Integral fungsi rasional, mahasiswa melakukan kebingungan dalam menentukan pemfaktoran penyebut, kesalahan ini menyebabkan kesalahan perhitungan algoritma, menyelesaikan proses dan soal tida ` $k$ dapat terselesaikan dengan baik.

8. Pada materi Substitusi pada integral tentu, mahasiswa sudah dapat menentukan hasil pengintegralannya namun terjadi kesalahan dalam perhitungan algoritma ketika menentukan integral tentunya, sehingga hasil yang diperoleh tidak tepat.

Hasil wawancara yang telah dilakukan selama pelaksanaan pembelajaran didapatkan data tentang faktor penting yang menyebabkan mahasiswa melakukan kesalahan dalam menyelesaikan soal-soal materi integral yaitu kurangnya latihan dalam mengerjakan soal-soal integral dan kurang pahamnya mahasiswa terhadap konsep teorema dasar kalkulus 
sebelumnya yaitu mengenai turunan sebagai materi prasyarat dalam menempuh dan mengikuti materi integral yang merupakan konsep utama yang diberikan dalam mata kuliah kalkulus integral yang juga merupakan prasyarat untuk menempuh mata kuliah berikutnya seperti persamaan diferensial, kalkulus peubah banyak, statistika matematika, dan lain-lain. Hasil yang diperoleh merupakan penjabaran dari data nilai yang diperoleh dan dipadukan dengan hasil wawancara terhadap mahasiswa sebagai subjek penelitian. Oleh karena itu, tidak menutup klemungkinan masih ada faktor-faktor lain yang menyebabkan mahasiswa mengalami kesulitan dalam menyelesaikan soal-soal materi integral, yang tidak terungkap baik dari hasil tes maupun dari hasil wawancara.

\section{KESIMPULAN}

Berdasarkan hasil penelitian dan pembahasan pada bab sebelumnya, dapat disimpulkan bahwa kesulitan belajar yang dialami mahasiswa terletak pada kemampuan matematis yang dimiliki mahasiswa dalam menyelesaikan soal-soal integral. Kemampuan tersebut meliputi lemahnya atau kurangnya pemahaman mahasiswa terhadap teorema dasar kalkulus terutama pada konsep turunan. Kesulitan yang dialami mahasiswa terletak pada kesalahan dalam memahami soal, kesalahan dalam keterampilan proses (termasuk kesalahan perhitungan algoritma, penulisan simbol, dan kesalahan pemisalan sebelum melakukan pengintegalan), serta kesalahan karena kurang cermat dalam mengerjakan soal dan mengelola waktu yang disediakan dalam menjawab dan menyelesaikan soal-soal integral sehingga soal tidak dapat terselesaikan dengan baik.

Hasil penelitian ini kemudian akan dijadikan bahan pertimbangan dalam pengembangan strategi pembelajaran yang efektif agar mahasiswa dapat lebih terasah kemampuannya dalam menyelesaikan soal-soal integral dan pengajar agar dapat memberikan latihanlatihan soal yang lebih bervariasi lagi kepada mahasiswa secara kontinu terutama berkaitan dengan ragam soal integral sehingga materi integral tidak lagi menjadi materi yang sulit bagi mahasiswa mengingat sangat pentingnya materi ini guna kelancaran mahasiswa dalam menempuh mata kuliah - mata kuliah berikutnya yang menjadikan materi integral ini sebagai prasyarat dalam mata kuliah tersebut.

\section{DAFTAR PUSTAKA}

Djamarah, Syaiful Bahri. (2008). Psikologi Belajar. Jakarta : Rineka Cipta..

Lerner. (1981). Learning Disabilities : Theories, Diagnosis, dan Teaching Strategies. Boston : Houghton Mifflin.

Mulyadi, H. (2010). Diagnosis Kesulitan Belajar dan Bimbingan Terhadap Kesulitan Belajar Khusus. Yogyakarta : Nuha Litera.

Nguyen Phu Loc dan Tran Cong Thai Ho. (2014). "A Survey Of 12th Grade Students 'Errors In Solving Calculus Problem," International Journal of Scientific \& Technology Research, vol 3 ISSUE 6 h. 1. [online]. Tersedia pada : https://pdfs.semanticscholar.org/33dc/9 19673b3e3de99f1e66b

ef993d2doef812ad.pdf. $\quad[20$ Januari 2018].

Sugiyono. (2011). Metode Penelitian Kuantitatif, Kualitatif, dan $R \& D$. Bandung : Alfabeta 